\title{
Pengaruh Jump Rope Training Terhadap Kekuatan Otot Tungkai pada Siswa Sekolah Dasar
}

\author{
Flavia Domitilla, Sri Yani \\ Program Studi D3 Fisioterapi, Fakultas Ilmu Kesehatan, \\ Universitas Pembangunan Nasional Veteran Jakarta
}

\begin{abstract}
Abstrak
Latar belakang: Kebugaran jasmani adalah hal yang penting dimiliki oleh setiap orang, terutama pada siswa sekolah dasar. Dengan memiliki kebugaran jasmani yang baik, anak dapat meningkatkan konsentrasi saat belajar di sekolah maupun di rumah. Salah satu komponen kebugaran jasmani adalah kekuatan otot. Pelatihan jump rope bermanfaat untuk kekuatan otot. Jump rope adalah program kebugaran terbukti memiliki teknik yang bermanfaat dan keunggulan efektif. Studi ini bertujuan untuk mengkaji manfaat jump rope training dalam meningkatkan kekuatan otot tungkai siswa SD.

Metode: Studi ini menggunakan desain kuasi eksperimen one sample population dengan pre and post test. Populasi penelitian ini adalah siswa SD Cinere 02 dengan kriteria inklusi dan ekslusi dan sampel 59 siswa. Sebelum pelatihan Jump rope dilakukan pengukuran kekuatan otot. Pelatihan jump rope diberikan selama 5 minggu, setelah itu dilakukan pengukuran kekuatan otot kembali.

Hasil: Data dianalisis dengan paired T-test, mean \pm SD pre-test laki-laki di dapatkan hasil 42,89 \pm 2,564 , perempuan $34,83 \pm 2,120$. Sedangkan mean $\pm S D$ post-test laki-laki 52,00 $\pm 4,116$ perempuaan 38,39 $\pm 3,040$. Dari hasil uji normalitas pre-test dan post-test laki-laki dan perempuan didapatkan nilai $p>0,05$ dan uji hipotesis menggunakan paired T-test didapatkan mean $\pm S D$ pre-test $37,29 \pm 4,363$, post-test 42,54 $\pm 71,61$ dan $p=0,001$.
\end{abstract}

Kesimpulan: Latihan jump rope yang selama 5 minggu dapat meningkatan kekuatan otot tungkai siswa SD Negeri Cinere 02.

Kata kunci : kebugaran jasmani, kekuatan otot tungkai, latihan jump rope

\section{The Effect of Jump Rope Training to Strength of Muscle in Elementary School Students}

\begin{abstract}
Background: Physical fitness is important for everyone, especially for elementary school students. By having good physical fitness, will improve their concentration while studying at school or home. One component of physical fitness is muscle strength. Jump rope training is beneficial for muscle strength. Jump rope is a fitness program proven to have useful techniques and effective advantages. This research aims to assess the benefits of jump rope training to improve the leg muscle strength of elementary school students.

Method: A one sample population of quasi-experimental method was done using pre and post-test design. The population of this study was elementary students of Cinere 02 who met the inclusion and exclusion criteria. The number of samples was 59 students. Before the Jump Rope training, a measurement of muscle strength is carried out. Jump rope training was given for 5 weeks, after which the muscle strength was measured again.

Results: Data were analyzed using paired sample T-test, the mean $\pm S D$ of the male pre-test was $42.89 \pm 2.564$, female $34.83 \pm 2.120$. While the mean $\pm S D$ post-test for men $52.00 \pm 4.116$, female 38 $38.39 \pm 3.040$. From the results of normality tests for male and female pre-test and post-test $p$ values $>$ 0.05 and hypothesis testing using paired sample T-test obtained mean \pm SD pre-test $37.29 \pm 4.363$, post-test $42.54 \pm 71.61$ and $p=0,001$.

Conclusion: A 5-week jump rope training can increase leg muscle strength of Cinere 02 Elementary School students.

Keywords: jump rope training, leg muscles strength, physical fitness

Alamat Korespondensi :

Sri Yani

Universitas Pembangunan Nasional Veteran Jakarta,

Jl. Raya Limo, Depok

Email: sri.yani@upnvj.ac.id
\end{abstract}




\section{PENDAHULUAN}

Usia 8-12 tahun adalah masa - masa di mana anak suka bermain. Di masa ini orang tua mempunyai peran penting dalam mendidik anak saat bermain. Orang tua dapat mengajarkan anak agar melakukan permainan dengan tujuan ke hal yang positif seperti untuk meningkatkan kebugaran jasmani. Kebugaran jasmani pada anak usia sekolah ada hubungan bermakna dengan tingkat konsentrasi ${ }^{1}$.

Kebugaran jasmani juga meningkatkan kebugaran fisik yang berhubungan dengan kesehatan yakni daya tahan otot kardiovaskuler, kekuatan dan daya tahan otot, fleksibilitas, dan komposisi tubuh. ${ }^{2}$ Kekuatan otot punggung dan kekuatan otot tungkai dapat memberikan validitas tertinggi dalam menilai kekuatan otot seluruh tubuh, dan juga memiliki validitas yang lebih tinggi pada anak-anak perkotaan dan pedesaan. ${ }^{3}$ Kekuatan otot tungkai bisa diartikan sebagai kemampuan otot - otot untuk menerima dan menahan beban maksimal pada tungkai dalam jangka waktu tertentu. Ada banyak latihan yang dapat digunakan untuk meningkatkan kekuatan otot tungkai pada anak sekolah dasar, diantaranya Jump Rope. Jump Rope dapat berkontribusi pada pengembangan keterampilan motorik anak-anak dan mempercepat perkembangan anak-anak. ${ }^{4}$

Jump Rope atau bisa disebut juga dengan Skipping Rope/lompat tali adalah salah satu dari bentuk latihan plyometric. ${ }^{5}$ Latihan lompat tali dapat meningkatkan koordinasi, keseimbangan, kelincahan, ritme, kecepatan dan terutama kekuatan otot statis atau dinamis. ${ }^{6}$ Lompat tali dilakukan oleh anak-anak sebagai hal yang menyenangkan. ${ }^{7}$

Jump Rope meningkatkan otot di lengan dan kaki, ${ }^{8}$ fungsi kardiovaskuler dan metabolisme. Ini juga memiliki efek positif pada kardiovaskuler, kekuatan otot, daya tahan, kecepatan, mobilitas dan fleksibilitas, kesimbangan, koordinasi, lompatan vertikal, pengaturan waktu, ritme dan kecepatan, massa tubuh, ${ }^{9}$ kepadatan tulang dan pengembangan keterampilan. ${ }^{10}$ Pada studi ini menerapkan jump rope pada siswa sekolah dasar. Tujuannya untuk mengkaji manfaat latihan jump rope terhadap kekuatan otot tungkai siswa sekolah dasar.

\section{METODE}

Metode peneitian ini menggunakan desain penelitiaan kuasi eksperimen, dengan pre-test dan post-test yang dilakukan tanpa kelompok kontrol atau one sample population. Latihan Jump rope dilakukan oleh siswa SD Cinere 02 selama 5 minggu dengan frekuensi tiga kali pertemuan per-minggu. Penelitian ini dilakukan di SD Cinere 02 dengan rentang waktu bulan April - Mei 2019.

Populasi penelitian ini adalah siswa SD Cinere 02 yang berjumlah 268 siswa. Sampel berjumlah 59 siswa, ditentukan sesuai dengan kriteria inklusi dan eksklusi. Kriteria inklusi yaitu siswa aktif, usia 8-12 tahun, sehat jasmani dan rohani, bersedia menjadi sampel (dengan persetujuan orang tua). Sedangkan kriteria eksklusi yaitu menderita penyakit serius (jantung, asma, vertigo, anemia), sedang mengalami cedera, pernah melakukan operasi dalam kurun waktu tiga bulan terakhir, dan tidak sedang menjadi sampel pada penelitian lain. Sedangkan kriteria drop out yaitu sampel tidak hadir lengkap selama proses penelitian, sedang dalam kondisi tubuh yang tidak sehat saat pelaksanaan, mengkonsumsi obat-obat saat menjadi sampel, dalam keadaan setelah makan 0-30 menit sebelum latihan, sampel menyatakan mengundurkan diri dari penelitian ini, dan cedera saat penelitian berlangsung.

Populasi sebanyak 268 orang yang terdiri dari 94 siswa kelas 3, 92 siswa kelas 4 dan 82 siswa kelas 5. Penentuan sampel menggunakan rumus Federer. Hasil yang didapatkan adalah $\geq$ 16 orang. Sampel dalam penelitian ini didapat dari siswa kelas 3, 4,dan 5 yang berjumlah 59 orang. Dari 59 siswa tersebut, dicari persentase dengan cara jumlah siswa per kelas dibagi dengan total jumlah siswa. Persentase tersebut digunakan untuk menentukan jumlah proposional yang akan diteliti setiap per kelasnya. Didapatkan 21 orang dari kelas 3, 20 orang dari kelas 4, 12 orang dari kelas 5 .

Data yang diperoleh dianalisis dengan menggunakan perangkat lunak analisis data untuk menguji univariat yakni menganalisis karateristik subjek penelitian dan bivariat untuk menguji normalitas data dan uji hipotesis paired T-test.

Variabel terikat pada studi ini adalah kekuatan otot tungkai dan variabel bebas, intervensi latihan jump rope. Kekuatan otot tungkai diukur dengan parameter vertical jump. Vertical jump adalah tes kebugaran yang secara umum digunakan untuk kekuatan otot tungkai atau daya ledak otot (explosive power) seorang atlet. Tes ini sering digunakan oleh altet profesional untuk mengetahui perkembangan selama latihan. Semakin tinggi loncatan semakin kuat otot tungkai/daya ledak otot seseorang. ${ }^{11}$

Latihan jump rope dilaksanakan dengan dosis $3 \mathrm{kali} /$ minggu, dengan intensitas sebagai 
berikut, minggu pertama 5 set selama 1 menit, minggu ke-2, 6 set 1 menit, minggu ke-3, 8 set 1 menit, minggu ke-4 10 set 1 menit, minggu ke-5 12 set 1 menit dengan tipe aerobic ${ }^{12}$. Penelitian ini memperoleh persetujuan etik dari Komite Etik Penelitian Kesehatan UPN Veteran Jakarta, dengan No.: B/1764/4/2019/KEPK tanggal 1 April 2019.

\section{HASIL}

Berdasarkan sampel 59 siswa, didapatkan karakteristik responden, Heart Rate (HR), Respiratory Rate (RR), dan Blood Pressure (BP) kategori 2 yakni kategori normal (Tabel 1).

\section{Tabel 1. Karakteristik Subjek Penelitian}

\begin{tabular}{|c|c|c|c|c|c|c|}
\hline \multirow{2}{*}{$\begin{array}{c}\text { Varia } \\
\text { bel }\end{array}$} & \multirow[b]{2}{*}{$\begin{array}{c}M i \\
n\end{array}$} & \multicolumn{2}{|c|}{$\begin{array}{l}\text { Perempuan } \\
(\mathrm{n}=41)\end{array}$} & \multicolumn{3}{|c|}{$\begin{array}{c}\text { Laki-Laki } \\
(\mathrm{n}=18)\end{array}$} \\
\hline & & $\begin{array}{c}M a \\
x\end{array}$ & $\begin{array}{c}\text { Mean } \pm \\
S D\end{array}$ & $\begin{array}{c}M i \\
n\end{array}$ & $\begin{array}{c}M a \\
x\end{array}$ & $\begin{array}{c}\text { Mean } \\
\pm S D\end{array}$ \\
\hline $\begin{array}{c}\text { Usia } \\
\text { (tahun } \\
\text { ) }\end{array}$ & 8 & 12 & $\begin{array}{c}9,66 \pm \\
0,91\end{array}$ & 8 & 12 & $\begin{array}{c}9,28 \\
\pm \\
0,95\end{array}$ \\
\hline$H R$ & 2 & 2 & $\begin{array}{c}2,00 \pm \\
0,00\end{array}$ & 2 & 2 & $\begin{array}{c}2,00 \\
\pm \\
0,00\end{array}$ \\
\hline$R R$ & 2 & 2 & $\begin{array}{c}2,00 \pm \\
0,00\end{array}$ & 2 & 2 & $\begin{array}{c}2,00 \\
\pm \\
0,00\end{array}$ \\
\hline$B P$ & 2 & 2 & $\begin{array}{c}2,00 \pm \\
0,00\end{array}$ & 2 & 2 & $\begin{array}{c}2,00 \\
\pm \\
0,00\end{array}$ \\
\hline $\begin{array}{l}\text { Tinggi } \\
\text { Badan }\end{array}$ & $\begin{array}{c}12 \\
7\end{array}$ & $\begin{array}{c}14 \\
2\end{array}$ & $\begin{array}{l}133,24 \\
\pm 4,40\end{array}$ & $\begin{array}{c}12 \\
9\end{array}$ & 146 & $\begin{array}{c}134,2 \\
2 \pm \\
4,02\end{array}$ \\
\hline $\begin{array}{l}\text { Berat } \\
\text { Badan }\end{array}$ & 28 & 46 & $\begin{array}{c}38,63 \pm \\
3,61\end{array}$ & 31 & 46 & $\begin{array}{c}38,50 \\
\pm \\
3,46\end{array}$ \\
\hline $\begin{array}{l}\text { BMI } \\
\text { (skor) }\end{array}$ & 1 & 3 & $\begin{array}{c}1,95 \pm \\
0,38\end{array}$ & 1 & 2 & $\begin{array}{c}1,94 \\
\pm \\
0,23\end{array}$ \\
\hline
\end{tabular}

Tabel 2. Karakteristik Kekuatan Otot Tungkai Pre-Test

\begin{tabular}{lcccc}
\hline & & \multicolumn{2}{c}{ Pre-test } & Tota \\
\cline { 3 - 4 } & & kurang & cukup & $1(\%)$ \\
\hline \multirow{3}{*}{ Jenis } & Laki-Laki & 16 & 2 & 18 \\
Kelamin & $(\mathrm{n}=18)$ & $(27,1 \%)$ & $(3,4 \%)$ & $(30$, \\
Siswa & & & & $5 \%)$ \\
& $\begin{array}{c}\text { Perempuan } \\
\end{array}$ & 33 & 8 & 41 \\
& $(\mathrm{n}=41)$ & & & $5 \%)$ \\
\hline \multirow{2}{*}{ Total (\%) } & & $49,9 \%)$ & $(13,6 \%)$ & $(69$, \\
& & $(83,1 \%)$ & $(16,9 \%)$ & $(100$ \\
& & & & $\%$
\end{tabular}

Sebelum diberi latihan jump rope (pretest), pada siswa laki-laki terdapat $27,1 \%$ dengan kategori kurang, dan 3,4\% dengan kategori cukup. Sedangkan pada siswa perempuan $55,9 \%$ dengan kategori kurang dan $13,6 \%$ dengan kategori cukup (Tabel 2).

Setelah diberi latihan jump rope (posttest). Pada siswa laki-laki terdapat $1,7 \%$ dengan kategori kurang, 11,9\% dengan kategori cukup, dan $16,9 \%$ dengan kategori baik. Sedangkan pada siswa perempuan $10,2 \%$ dengan kategori kurang, 45,8\% dengan kategori cukup, dan 13,6\% dengan kategori baik (Tabel 3).

Tabel 3. Karakteristik Kekuatan Otot Tungkai Post-Test

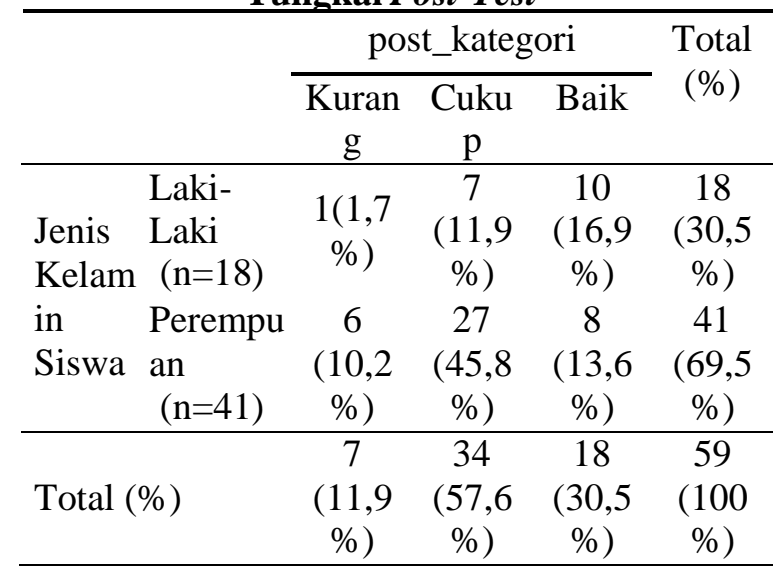

Tabel 4. Uji Hipotesis

\begin{tabular}{|c|c|c|c|}
\hline Variabel & $\begin{array}{c}\text { Nilai Uji } \\
\text { Paired } T \text {-test } \\
\text { Mean } \pm \text { SD }\end{array}$ & $\begin{array}{l}\text { Sig. (2- } \\
\text { tailed) } \\
\text { (P) }\end{array}$ & Ket. \\
\hline Pre- test & $37,29 \pm 4,363$ & & \\
\hline Post-test & $42,54 \pm 7,161$ & .000 & kan \\
\hline
\end{tabular}

Uji perbedaan kekuatan otot sebelum dan sesudah perlakuan terlihat bahwa pada pre test dan post test diperoleh nilai $\mathrm{p}=0,001$ ini menunjukan bahwa $\mathrm{p}<0,05$ maka nilai hipotesis dinyatakan signifikan. Artinya terdapat perbedaan yang signifikan antara sebelum dan setelah dilakukan latihan jump rope terhadap kekuatan otot tungkai pada siswa SD Negeri Cinere 02 (Tabel 4).

\section{PEMBAHASAN}

Subjek yang didapat sesuai dengan kriteria sampel berjumlah 59 orang, yang terdiri dari 18 siswa laki - laki dan 41 siswa perempuan. Penelitian ini dilaksanakan selama 5 minggu dengan frekuensi latihan 3 kali seminggu. Berdasarkan hasil analisis data yang telah dilakukan pada uji deskriptif didapatkan hasil tekanan darah (BP), Heart rate (HR), 
Repiratory Rate $(R R)$, berat badan, tinggi badan, usia dan Body Mass Index (BMI).

\section{Kekuatan Otot Tungkai Pada Siswa}

Pada studi ini salah satu faktor yang mempengaruhi kekuatan otot adalah tinggi badan. Dilihat dari hasil penelitian yang telah dilakukan pada siswa SD Negeri Cinere 02 didapatkan nilai rerata dan standar deviasi lakilaki 134,22 $\pm 4,02 \min 129 \mathrm{~cm}, \max 146 \mathrm{~cm}$, sedangkan pada siswa perempuaan rerata 133,24 $\pm 4,40 \mathrm{~min} 127 \mathrm{~cm}$, $\max 142 \mathrm{~cm}$.

Kekuatan adalah kemampuan maksimal seseorang untuk mengangkat suatu beban, dengan demikian bahwa otot yang kuat akan membuat kerja otot secara efisien seperti berjalan, berlari, melompat dan lain sebagainya yang juga akan membuat bentuk tubuh menjadi lebih baik. Otot-otot yang tidak terlatih akan menjadi lemah karena serabutnya kecil (atropi), dan bila hal ini dibiarkan dapat mengakibatkan kelumpuhan otot. ${ }^{13}$

Kekuatan otot penting bagi siswa karena apabila siswa memiliki otot yang kuat maka tidak akan mudah merasa lelah saat bermain atau beraktivitas sehingga membuat waktu beraktifitasnya menjadi lebih panjang. Di sisi lain siswa juga dapat meningkatkan kemampuaan prestasi non akademik. Manfaat bagi siswa dengan memiliki kekuatan otot yang baik dapat melindungi siswa tersebut dari cedera yang dapat terjadi saat siswa beraktivitas. Besar kecilnya otot bisa dilihat dengan menggunakan pengukuran antropometri. Antropometri berasal dari kata anthropos dan metros. Anthropos artinya tubuh dan metros artinya ukuran. Antropometri dapat diartikan secara jelas yaitu merupakan suatu ilmu yang berkaitan secara khusus menyangkut dimensi tubuh manusia. Pengukuran antropometri berupa pengukuran lingkar tungkai atas dan tungkai bawah.

\section{Pengaruh Jump Rope Training Terhadap Peningkatan Kekuatan Otot}

Kekuatan otot merupakan salah satu komponen penting kebugaran jasmani. Kekuatan otot tungkai sangat berperan penting dalam kehidupan sehari - hari, dikarenakan tungkai merupakan anggota gerak yang penting bagi tubuh. Apabila terjadi kelemahan pada otot tungkai maka, akan mengalami gangguan pada pergerakan tungkai. ${ }^{12}$ Kekuatan otot adalah kekuatan atau tegangan sebuah otot atau lebih yang bekerja melawan suatu tahanan dengan usaha maksimal. Kekuatan otot adalah kemampuan sekelompok otot yang melakukan kontraksi maksimal melawan beban. ${ }^{14}$

Peningkatan kekuatan otot tungkai ini disebabkan karena tubuh telah mengalami adaptasi terhadap olahraga yang diberikan. Sebagai akibat dari bertambahnya myofibril pada setiap serabut otot, meningkatnya densitas (kepadatan) kapiler pada setiap serabut otot, meningkatnya jumlah protein, dan bertambah jumlah serabut otot. Peningkatan kekuatan otot ini terjadi akibat adanya hypertrophy (pembesaran) otot. $^{5}$ Jika otot terlatih maka kekuatan otot pun akan meningkat. Salah satu latihan yang digunakan untuk meningkatkan kekuatan otot adalah Jump Rope Training. Pemberian jump rope training selama 5 minggu (3x seminggu) sesuai dengan frekuensi dan intensitas yang sudah di berikan akan dapat meningkatkan kemampuaan kekuatan otot secara maksimal

\section{KETERBATASAN STUDI}

Keterbatasan studi ini adalah sampel yang seharusnya diambil mulai dari kelas 2 sampai kelas 6 , namun yang dapat diambil hanya kelas 3 sampai kelas 5. Dikarenakan tidak mendapat izin dari kepala sekolah untuk menggunakan sampel kelas 2 dan 6 . Tidak dilakukan pengukuran antropometri lingkar tungkai atas dan bawah untuk mengetahui hubungan besar otot dengan kekuatan otot.

\section{KESIMPULAN}

Berdasarkan hasil studi dan pembahasan dapat disimpulkan bahwa Latihan Jump rope yang sudah dilakukan selama 5 minggu dapat meningkatan kekuatan otot siswa SD Negeri Cinere 02

\section{UCAPAN TERIMA KASIH}

Penelitian ini didukung / didukung sebagian oleh UPN Veteran Jakarta dan Komite Etika Penelitian Kesehatan UPNVJ. Kami berterima kasih kepada kolega kami dari anak SD Cinere 02 yang memberikan wawasan dan keahlian yang sangat membantu penelitian ini.

\section{DAFTAR PUSTAKA}

1. Sudrajat, A., Mexitalia, M., \& Rosidi, A. Status hidrasi, tingkat kebugaran jasmani dan daya konsentrasi anak sekolah dasar. Jurnal Gizi Indonesia: 2019;109-113.

2. Weiyun, C., Austin, B. H., Andrew, H., \& Steve, M. Health-related physical fitness and physical activity school 
students. BMC Public Health: 2018;112.

3. Liqin, Y., Changfa, T., \& Xia , T. Criterion-Related Validity of a Simple Muscle Strength Test to Assess Whole Body Muscle Strength in Chinese Children Aged 10 to 12 Years. Biomed Research International: 2018; 11 pages.

4. Nebahat, E., \& Hakan, A. The Effects of the Rope Jump Training Program in Physical Education Lessons on Strength, Speed and VO2 max in Children. Universal Journal of Educational Research: 2018; 340-345.

5. Kannappan, T., \& Sivasankar, S. Effect of varied specific training on skill performance variables among school. 2018

6. Kirthika, S., Laksmanan, R., Padmanabhan, K., Subdhakar, S., \& Selvam, P. The Effect of Skipping rope Exercise on Physical and Cardiovaskuler fitness among Collegiate Males. Research Journal of Pharmacy and Technology: 2019; 4831-4835.

7. Aagaard, M. Rope Training Fitness: The Complete Guide to Jump Rope Fitness. Human Kinetics: 2012;80-81.
8. Chen CC, \& Lin SY. The Impact of Rope Jumping Exercise on Physical Fitness of Visually Impaired Students. Res Dev Disabil : 2011;25-29.

9. Cooper, K. Benefits of Rope Jumping. 2006

10. Chao-Chien, C., \& Yi-Chun, L. (2012). Jumping Rope Intervention on HealthRelated Physical Fitness in Student with Intellectual Impairment. The Journal of Human Resource and Adullt Learning: 2012;56-62.

11. Michelle Lovitt, \& John Speraw. Exercise for Your Muscle Type. ReadHowYouWant.com. 2010

12. Haghighi, A. Comparing the Effect of Jump Rope Training on Physical and Motor Fitness Components Among Primary School Boy and Girl. 2018

13. Komarudin. Analisis Tingkat kesegaran Jasmani terhadap Prestasi Belajar Siswa SD Negeri Bawakaraeng III Makasar. 2018; Vol 1, no, 2; hlm. 85-93

14. Widiastuti. Tes dan Pengukuran Olahraga, Jakarta: PT Bumi Timur Jaya. 2011 